\title{
EFEKTIVITAS ECENG GONDOK (Echhornia crassipes) DALAM PENYERAPAN KADMIUM (Cd) PADA LEACHATE TPA GUNUNG TUGEL
}

\author{
Sri Lestari, Slamet Santoso dan Sulastri Anggorowati \\ Fakultas Biologi Universitas Jenderal Soedirman Purwokerto \\ email : tari.bio@gmail.com
}

\begin{abstract}
Leachate is liquid of result organic garbage that contain substance is dissolved and suspension as decomposition by microorganism. Leachate contain material organic with high level and many formed at landfill with open dumping system. Material organic in leachate can be reduced by phytoremediation with water hyacinth (Echhornia crassipes). The aim of research are know large closure of water hyacinth, long residence time and the best interaction to reduce the levels of material organic in leachate. Method of research was designed experimental based on Completely Randomized Design (CRD) with Factorial Design. The first factor are closing large percentage of water hyacinth $(0 \%, 25 \%$, $50 \%, 75 \%$ and 100\%) and the second factor are long residence time (4 days, 5 days and 6 days). Result of research showed that is closing large of $75 \%$ is the best treatment to reducing level of $\mathrm{Cd}$ that is 29,279\%. and long residence time of 6 days is the best treatment to reducing level of $\mathrm{Cd}$ that is $27,211 \%$. Interaction closing large of $75 \%$ and long residence time of 6 days is the best treatment to reducing level of $\mathrm{Cd}$ that is $39,770 \%$
\end{abstract}

Keyword : Phytoremediation, Echhornia crassipes, Leachate, Cd

\section{PENDAHULUAN}

Sampah merupakan permasalahan lingkungan cukup serius yang masih dihadapi Indonesia. Rata-rata satu orang per hari menghasilkan sampah 1-2 kg, dan akan terus meningkat sejalan dengan meningkatnya kesejahteraan dan gaya hidup masyarakat. Kabupaten Banyumas memiliki empat buah TPA, salah satunya adalah TPA Gunung Tugel yang berlokasi di Desa Kedungrandu, Kecamatan Patikraja. Sumber sampah terbesar di TPA Gunung Tugel adalah pemukiman (rumah tangga), disusul pasar, pertokoan dan industri. TPA Gunung Tugel menghasilkan sampah 260 $\mathrm{m}^{3} /$ hari dengan komposisi tertinggi berupa bahan organik yaitu $61,91 \%$ (Cahyono, et., al. 1999). Bahan organik pada sampah teronggok akan mengalami dekomposisi menghasilkan leachate (air lindi). Leachate adalah cairan yang mengandung zat terlarut dan tersuspensi yang sangat halus sebagai hasil penguraian oleh mikroba (Soemirat, 1999). Menurut Fachrudin (1989) leachate dicirikan oleh bahan organik berkadar tinggi serta mengandung logam berat.

Sistem pengelolaan leachate di TPA Gunung Tugel kurang optimal. Debit leachate yang tertampung dalam bak-bak pengolahan adalah 0,8988 $\mathrm{m}^{3} /$ hari (Dinas Lingkungan Hidup Kabupaten Banyumas, 2006) sedangkan sebagian besar merembes ke tanah. Menurut Keman (2003) leachate yang dibiarkan tanpa diolah akan mencemari air tanah di sekitarnya. Jenis tanah di TPA Gunung Tugel adalah ultiosol sehingga memungkinkan leachate dapat merembes dan mencemari air tanah penduduk di sekitarnya.

Sebagai upaya mengatasi pencemaran tersebut maka perlu dilakukan pengelolaan terhadap leachate yang dihasilkan oleh TPA Gunung Tugel. Bahan organik dan logam berat yang terdapat di dalam limbah dapat dikurangi 
menggunakan eceng gondok (Eichhornia crassipes) melalui proses fitoremidiasi baik pada skala laboratorium maupun lapangan. Dalam rangka mengurangi kadar bahan organik dan logam berat pada leachate TPA Gunung Tugel, maka tujuan penelitian adalah:

1. Mendapatkan luas penutupan eceng gondok dan lama waktu tinggal yang mampu menurunkan kadar Cd pada leachate secara optimal.

2. Mendapatkan kombinasi luas penutupan eceng gondok dan lama waktu tinggal yang mampu menurunkan kadar Cd pada leachate secara optimal

\section{METODE PENELITIAN}

Metode penelitian yang digunakan adalah metode eksperimental yang disusun berdasarkan Rancangan Acak Lengkap (RAL) dengan pola Faktorial. Perlakuan yang dicobakan yaitu prosentase luas penutupan eceng gondok $(0 \%, 20 \%, 50 \%, 75 \%$ dan $100 \%)$ lama waktu tinggal (4 hari, 5 hari dan 6 hari). Kombinasi perlakuan yang diperoleh adalah 15 perlakuan, masing-masing perlakuan diulang sebanyak 3 kali.

Perlakuan fitoremediasi dilakukan dalam skala laboratorium menggunakan ember plastik volume 20 liter sebanyak 45 buah, masing-masing diisi dengan 10 liter leachate. Setiap ember ditambahkan eceng gondok dengan luas penutupan $0 \%, 25 \%, 50 \%, 75 \%$ dan $100 \%$. Ember plastik kemudian didiamkan selama 4 hari, 5 hari dan 6 hari. Kadar Cd diukur sebelum dan sesudah perlakuan mengikuti metode Herlich (1991). Perhitungan persentase penurunan kadar $\mathrm{Cd}$ berdasarkan hasil penelitian Yusnita (2007).

Data yang diperoleh dianalisis dengan menggunakan uji $F$ untuk mengetahui adanya pengaruh antar perlakuan kemudian dilanjutkan dengan Uji Beda Jujur (BNJ) untuk mengetahui prosentase luas penutupan dan lama waktu tinggal yang paling optimum dalam menurunkan kadar $\mathrm{Cd}$.

\section{HASIL DAN PEMBAHASAN}

Berdasarkan data hasil pengukuran konsentrasi $\mathrm{Cd}$ pada leachate TPA Gunung Tugel dengan perlakuan luas penutupan eceng gondok dan lama waktu tinggal, persentase penurunan $\mathrm{Cd}$ terbesar terdapat pada perlakuan luas penutupan $75 \%$ dan lama waktu tinggal 6 hari, yaitu sebesar $39,770 \%$, sedangkan persentase penurunan $\mathrm{Cd}$ terkecil sebesar 9,344\% terdapat pada perlakuan luas penutupan 0\% dan lama waktu tinggal 5 hari. Penurunan $\mathrm{Cd}$ dengan perlakuan luas penutupan dan waktu tinggal disajikan selengkapnya dalam Gambar 1. Cd terserap melalui akar pada saat eceng gondok melakukan proses fotosintesis. Proses penyerapan logam secara aktif dengan adanya molekul $\mathrm{H}^{+}$di dalam membran yang membentuk kompleks dan mengangkut ion logam.

Berdasarkan Gambar 1 semakin besar luas penutupan dan lama waktu tinggal eceng gondok, persentase penurunan $\mathrm{Cd}$ akan semakin meningkat, namun titik tertentu akan mengalami kejenuhan. Kejenuhan tersebut diduga karena eceng gondok menyerap semua zat-zat yang berada dalam leachate, semakin banyak zat-zat yang terserap maka akan menumpuk dalam jaringan tanaman dan menyebabkan kejenuhan sehingga penyerapan akan terhambat.

Hasil analisis varian persentase penurunan $\mathrm{Cd}$ dengan luas penutupan eceng gondok dan waktu tinggal yang berbeda disajikan pada Tabel 1 . 


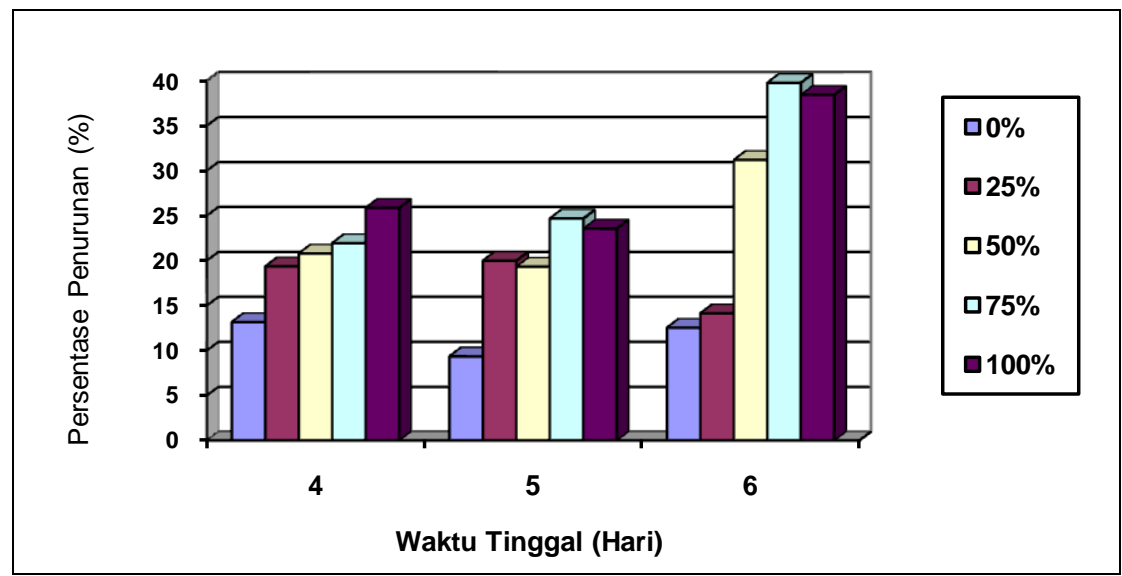

Gambar 1. Histogram penurunan $\mathrm{Cd}$ pada leachate dengan perlakuan luas penutupan eceng gondok dan lama waktu tinggal

Tabel 1. Analisis varians (uji F) perlakuan luas penutupan eceng gondok dan lama waktu tinggal dalam menurunkan kadar $\mathrm{Pb}$ dan $\mathrm{Cd}$ pada leachate

\begin{tabular}{|c|c|c|c|c|c|c|c|}
\hline \multirow[b]{2}{*}{ Parameter } & \multirow{2}{*}{$\begin{array}{l}\text { Sumber } \\
\text { Ragam }\end{array}$} & \multirow{2}{*}{$\mathrm{db}$} & \multirow{2}{*}{ JK } & \multirow{2}{*}{ KT } & \multirow{2}{*}{ Fhit } & \multicolumn{2}{|c|}{ Ftabel } \\
\hline & & & & & & 0.05 & 0.01 \\
\hline \multirow{7}{*}{$\mathrm{Cd}$} & Waktu Tinggal & 2 & 555.245 & 277.622 & \multirow[t]{3}{*}{$6.3792^{*}$} & \multirow[t]{2}{*}{5.14} & \multirow{3}{*}{10.92} \\
\hline & Galat a & 6 & 261.120 & 43.520 & & & \\
\hline & Luas & & & & & & \\
\hline & Penutupan & 4 & 2032.108 & 508.027 & $7.1353 * *$ & 2.76 & 4.18 \\
\hline & $\mathrm{T} \times \mathrm{L}$ & 8 & 3309.017 & 413.627 & $5.8095 * *$ & 2.34 & 3.32 \\
\hline & Galat b & 24 & 1708.776 & 71.199 & & & \\
\hline & Total & 44 & & & & & \\
\hline & gan: & $a k$ & & & & & \\
\hline
\end{tabular}

Penurunan kadar Cd disebabkan karena eceng gondok mampu menyerap dan mengakumulasi logam berat dalam jaringan akar dan daun. Proses absorpsi Cd pada eceng gondok dapat dikategorikan sebagai fitoremidiasi. Menurut Khiji and Bareen (2008) salah satu proses penting dalam fitoremidiasi adalah rhizofiltrasi. Rhizofiltrasi merupakan pengendapan zat kontaminan seperti logam berat oleh akar dengan bantuan zat pengkhelat. Penyerapan logam berat oleh tanaman dilakukan jika konsentrasi logam dalam media cukup tinggi. Semakin tinggi konsentrasi polutan maka proses rhizofiltrasi semakin meningkat. Tanaman mempunyai mekanisme tertentu untuk mencegah keracunan logam terhadap sel salah satunya dengan menimbun logam dalam organ tertentu seperti akar (Siswoyo, 2006). Salisbury dan Ross (1995) menyatakan bahwa spesies tanaman yang tumbuh dilingkungan tercemar logam akan mengalami stres metal dengan membentuk zat fitokhelatin khususnya dibagian akar sebagai mekanisme toleransi yang penting. Fitokhelatin merupakan peptida kecil yang kaya asam amino sistein yang mengandung belerang. Atom belerang dalam sistein ini yang akan mengikat logam berat dari media tumbuh.

Interaksi luas penutupan $75 \%$ dan waktu tinggal 6 hari merupakan perlakuan terbaik dalam menurunkan kadar $\mathrm{Cd}$ pada leachate. Perbedaan persentase penurunan $\mathrm{Cd}$ sangat 
dipengaruhi oleh $\mathrm{pH}$ media. Berdasarkan hasil penelitian $\mathrm{pH}$ media cenderung mengalami penurunan. Nilai $\mathrm{pH}$ awal berkisar $8,33-8,40$ mengalami penurunan dengan kisaran 7,63 - 8,33 pada akhir penelitian. Menurut Liani (2004), adanya asam (ion $\mathrm{H}^{+}$) dalam limbah cair akan diikat oleh ion $\mathrm{HCO}^{3-}$ membentuk $\mathrm{H}_{2} \mathrm{CO}_{3}$ yang kemudian terurai menjadi $\mathrm{H}_{2} \mathrm{O}$ dan $\mathrm{CO}_{2} . \mathrm{pH}$ mengindikasikan keseimbangan asam basa di dalam limbah cair terutama adalah adanya asam lemah $\mathrm{H}_{2} \mathrm{CO}_{3}$ dan basa konjugasinya $\mathrm{HCO}^{3-}$. Campuran inilah yang dapat mempertahankan $\mathrm{pH}$ limbah cair mendekati netral. Pada $\mathrm{pH}$ mendekati netral, $\mathrm{CO}_{2}$ terdapat dalam bentuk bebas dan sebagian dalam bentuk ion bikarbonat.

\section{KESIMPULAN}

1. Luas penutupan eceng gondok $75 \%$ optimal menurunkan $\mathrm{Cd}$ sebesar $29,279 \%$. Waktu tinggal 6 hari optimal dalam menurunkan kadar $\mathrm{Cd}$ sebesar 27,211\%.

2. Kombinasi luas penutupan $75 \%$ dengan lama waktu tinggal 6 hari optimal dalam menurunkan $\mathrm{Cd}$ adalah $39,770 \%$.

\section{UCAPAN TERIMA KASIH}

Ucapan terima kasih disampaikan pada Proyek Indonesia - Managing Higher Education for Relevance and Efficieny (I-MHERE) Universitas Jenderal Soedirman yang telah membiayai penelitian ini.

\section{DAFTAR PUSTAKA}

Arundina, M. 2002. Peningkatan Kualitas Air Limbah Batik Plenthong dengan Kayambang (Salvinia natans All).(Skripsi tidak dipublikasikan). Fakultas Biologi Universitas Gadjah Mada. Yogyakarta.
Cahyono, T.B., Triyantoro dan Z. Budiono. 1999. Kaji Tindak Pengelolaan Sampah di Kabupaten Banyumas Tahun 1998/1999. Depkes RI. Pusat Pendidikan Kesehatan, Purwokerto.

Dinas Lingkungan Hidup Kabupaten Banyumas. 2006. Laporan Akhir. Perencanaan Teknis Pengembangan TPA Gunung Tugel Kecamatan Patikraja Kabupaten Banyumas. Dinas Lingkungan Hidup, Banyumas.

Fachrudin, A. 1989. Pengaruh Sampah di Tempat Pembuangan Akhir Dago Kotamadya Bandung Terhadap Kualitas Air Tanah Bebas di Sekitarnya. Tesis, Sekolah Pascasarjana Universitas Gadjah Mada, Yogyakarta.

Herlich, K. 1991. Official Methods of Analisis. AOAC, Virginia, USA.

Keman, S. 2003. Pengaruh Pembuangan Sampah Terbuka (Open Dumping) Terhadap Kualitas Kimia Air Sumur Gali Penduduk di Sekitarnya. Jurnal Penelitian Medika Eksakta Vol. 4 No. 2 Agustus 2003: $147-156$.

Khiji, S and F.E Bareen. 2008. Rhizofiltration of Heavy Metals from the Tannery Sludge by the Anchored Hydrophyte, Hydrocotyle umbellata L. African Journal of Biotechnology 7 (20) : 3711-3717.

Liani, F. 2004. Pemanfaatan Kayu Apu (Pistia stratioles, L.) Sebagai Fitoremidiator Limbah Cair Industri Pelapisan Krom. Skripsi (tidak dipublikasikan). Fakultas Biologi. Universitas Jenderal Soedirman, Purwokerto.

Salisbury, FB \& CW. Ross. 1995. Fisiologi Tanaman. UGM Press. Yogyakarta.

Siswoyo, E. 2006. Fitoremidiasi Logam Berat Khrom (Cr) Menggunakan Tanaman Air Kiapu (Pistia 
Efektivitas Eceng Gondok (Echhornia crassipes) Dalam ... (Sri Lestari, dkk)

stratiotes). Jurnal Teknik Lingkungan Edisi Khusus 1 : 291300.

Soemirat, J. 1999. Kesehatan Lingkungan. Yogyakarta: Gadjah Mada University Press.
Yusnita, R. 2007. Model Matematik pada Pengolahan limbah cair tahu secara Biofiltrasi menggunakan Eceng Gondok ((Eichhornia crassipes (Mart). Solms). Skripsi (tidak dipublikasikan). Fakultas Pertanian. Universitas Jenderal Soedirman, Purwokerto. 